\title{
Homoharringtonine and omacetaxine for myeloid hematological malignancies
}

\author{
Shuqing Lü and Jianmin Wang ${ }^{*}$
}

\begin{abstract}
Homoharringtonine $(H H T)$, a plant alkaloid with antitumor properties originally identified nearly 40 years ago, has a unique mechanism of action by preventing the initial elongation step of protein synthesis. HHT has been used widely in China for the treatment of chronic myeloid leukemia (CML), acute myeloid leukemia (AML) and myelodysplastic syndrome (MDS). Omacetaxine, a semisynthetic form of HHT, with excellent bioavailability by the subcutaneous route, has recently been approved by FDA of the United States for the treatment of CML refractory to tyrosine kinase inhibitors. This review summarized preclinical and clinical development of HHT and omacetaxine for myeloid hematological malignancies.
\end{abstract}

Keywords: Homoharringtonine, Omacetaxine, Chronic myeloid leukemia, Acute myeloid leukemia, Myelodysplastic syndrome

\section{Background}

The genus Cephalotaxus comprises nine species, which are mostly concentrated in China, but are also found in eastern India, Thailand, the Korean peninsula and Japan. The anti-inflammatory and antiparasitic effects of Cephalotaxus fortunei Hook plants have been used in Chinese folk remedies for a long time and its antineoplastic effects have also been studied [1]. Paudler et al. [2] isolated harringtonine and cephalotaxine from Cephalotaxus harringtonia in 1963 for the first time. In 1969, Powell et al. [3,4] determined their structures and confirmed the antileukemic effects on mouse P-388 and L-1210 lines of some ester alkaloids isolated from Cephalotaxus harringtonia: harringtonine, isoharringtonine, deoxyharringtonine, and homoharringtonine (HHT). HHT differs from harringtonine in that it has a methylene group inserted in the side chain. Chinese scientists conducted research that confirmed the antileukemia effects of harringtonine and HHT in patients with acute myeloid leukemia (AML) and chronic myeloid leukemia (CML). In most of those studies, a racemic mixture of harringtonine and HHT was used. Despite similar chemical and preclinical activities, HHT was chosen over harringtonine because of its better extraction yield from its source, Cephalotaxus harringtonia [5-7]. A series of

\footnotetext{
* Correspondence: jmwang@medmail.com.cn

Department of Hematology, Changhai Hospital, Second Military Medical University, 168 Changhai Road, Shanghai 200433, China
}

studies conducted in the United States confirmed the utility of this agent for CML $[8,9]$. Since then, harringtonine and HHT have been widely used in the treatment of CML, AML and myelodysplastic syndrome (MDS), especially in China [10-13]. However, the clinical development of HHT in CML stopped with the discovery and popularization of the tyrosine kinase inhibitor (TKI), imatinib mesylate (Gleevec) [14]. Recently, the interest in HHT for CML has been encouraged by positive results in patients who failed on imatinib therapy.

The natural purification of harringtonine and HHT has caused significant damage to the environment. In 1999, Robin et al. [15] reported, for the first time, the synthesis of semisynthetic HHT (sHHT). sHHT involves the direct esterification of cephalotaxine extracted from dry leaves of cephalotaxus, not from the bark. Only one 70th of the amount of cephalotaxus is required to extract sHHT compared with its natural counterpart, and it is also purer (99.7\%). In addition, sHHT has excellent bioavailability by the subcutaneous (SC) route. SHHT is known currently as omacetaxine mepesuccinate (ceflatonin, CGX-653, Myelostat) and is being developed by ChemGenex Pharmaceuticals Ltd. (Menlo Park, CA, USA), in collaboration with Stragen Pharma (Geneva, Switzerland). Omacetaxine has recently been proved by FDA of the United States as an orphan drug to treat CML patients resistant to TKIs. In this paper, we will 
review the unique mechanism of action, and the development of HHT and omacetaxine for the treatment of hematological malignancies.

\section{Mechanisms of action and preclinical studies}

Harringtonine and HHT inhibit protein translation by preventing the initial elongation step of protein synthesis via an interaction with the ribosomal A-site [16,17]. Recent crystallographic studies have shown that HHT blocks protein synthesis by competing with the amino acid side chains of incoming aminoacyl-tRNAs for binding to the A-site cleft in the peptidyl transferase center of the ribosome [18]. HHT leads to a general decrease in synthesis efficiency of all proteins. An important short-term effect of HHT on cells is the rapid loss of proteins with short half-lives. A number of proteins related to cell survival and proliferation with short half-lives are encoded by mRNAs that possess complex 5' UTRs that are G/C rich and have complex 3-dimensional structures (e.g. c-Myc, Mcl-1 and Cyclin D1). HHT and omacetaxine induce the rapid loss of a number of short-lived proteins from various cell lines of hematological malignancies. These short-lived proteins clearly regulate proliferation and cell survival and their loss is likely to be involved in the apoptosis induced by HHT and omacetaxine. An early event that triggers HHT- and omacetaxine-induced apoptosis is the downregulation of Mcl-1, which was originally identified as an antiapoptotic $\mathrm{Bcl}-2$ family protein during differentiation of myeloid cells. These effects were replicated in primary cells obtained from patients with AML and patients with CML. Mcl-1 downregulation may result in an increase in free BH3-only proteins, such as Bim, tBid, Bik, and Puma, in addition to reducing the levels of beta-catenin and Xlinked inhibitor of apoptosis (XIAP) proteins [19-24]. The short-lived protein $\mathrm{c}-\mathrm{Myc}$ can promote expression of elongation initiation factor $4 \mathrm{~F}$ (eIF-4 F) proteins, which feed forward to promote translation of mRNAs that possess complex 5' UTRs including c-Myc. As c-Myc is preferentially lost from cells treated with HHT, levels of mRNAs encoding eIF-4 F proteins are likely to be rapidly reduced and augment the effects of downregulation of protein translation initiation $[25,26]$.

In vitro studies showed that HHT could induce apoptosis of AML and MDS cells via upregulation of pro-apoptotic bax and downregulation of the protein inhibitor survivin $[24,27,28]$. Moreover, a study by Tong et al. showed that HHT might act as a broad-spectrum protein tyrosine kinase inhibitor that inhibits the phosphorylation of the signal proteins by oncogenic proteins such as JAK2V617F, Bcr$\mathrm{Abl}$, thus blocking the survival and proliferative signal pathway of primary AML cells and AML cell lines such as HEL, K562 and HL-60 cells [29].

This effect of HHT is similar to other novel protein translation inhibitors, such as silvestrol. However, the mechanisms of these protein translation inhibitors are different (Figure 1). Silvestrol is a cyclopenta benzofuran rocaglate isolated from the Indonesian plant Aglaia foveolata, which has a unique dioxanyl ring-containing side chain. Silvestrol interferes with the assembly of the eIF4F translation complex by promoting an aberrant interaction between capped mRNA and eIF4A, thereby blocking protein synthesis at the initiation step. This inhibition of protein

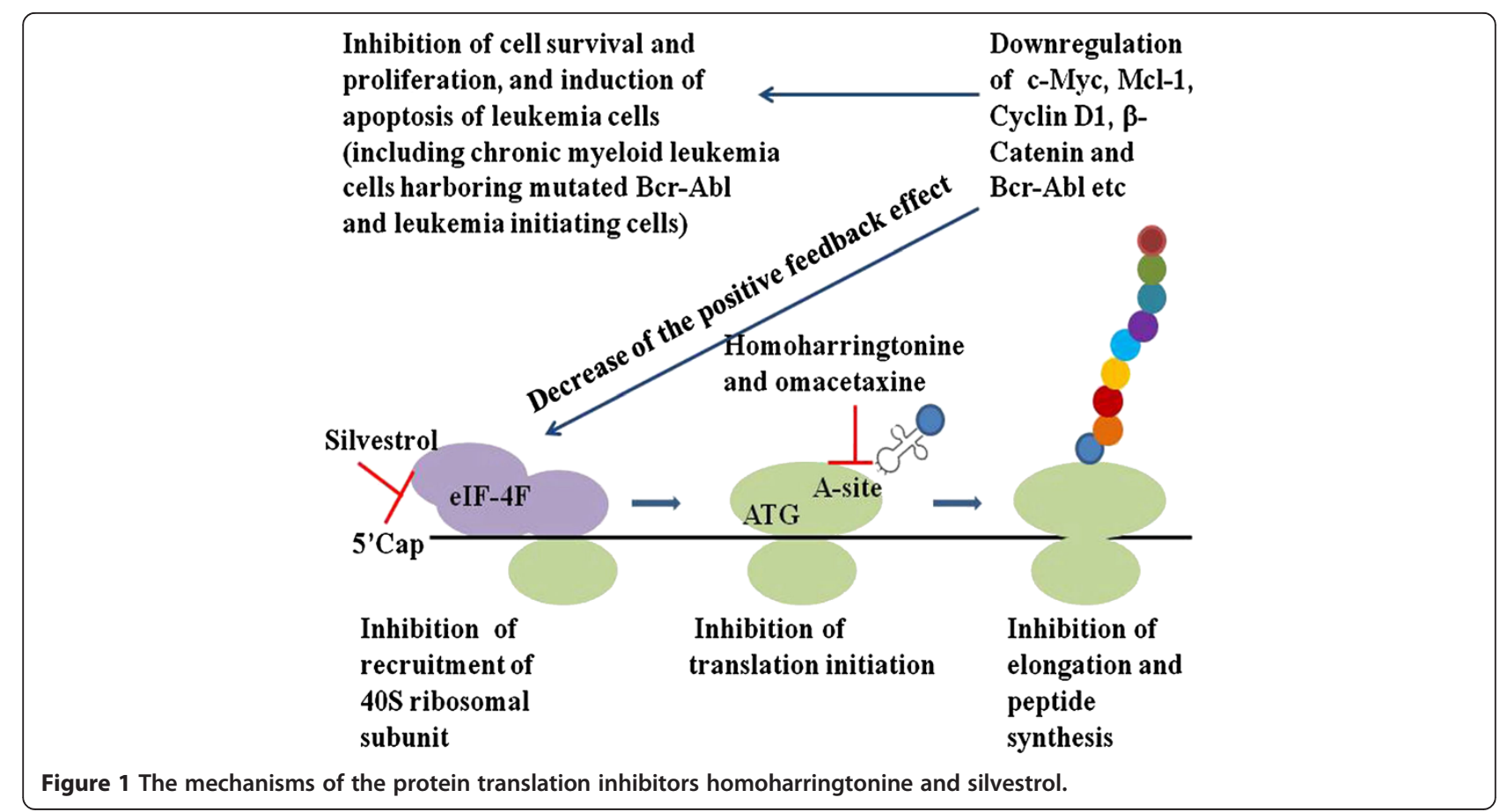


synthesis by silvestrol also results in a preferential depletion of proteins with short half-lives, such as Mcl-1, Cyclin D1 and c-Myc. Silvestrol was reported to have activity against leukemia cells in vitro and in vivo [30,31].

Interestingly, HHT has proved synergistic with other agents active in CML, such as IFN-a, cytosine arabinoside (Ara-C), or both combined. The combination of all three agents was highly active against leukemic cells from patients with CML in the chronic phase (CML-CP) [32]. Protein translation of mRNAs with complex $5^{\prime}$ UTRs in Bcr-Abl positive cells is upregulated via Bcr-Ablmediated activation of phosphoinositide-3-kinase (PI3K)/ AKT/mammalian target of rapamycin (mTOR) signaling pathways [33]. The inhibition of Bcr-Abl by imatinib markedly reduced protein translation initiation. Imatinib interacts synergistically in inducing apoptosis of Bcr-Abl positive cells with compounds that interfere with translation directly or regulate protein translation initiation, which includes HHT and omacetaxine. HHT and omacetaxine also reduce Bcr-Abl protein levels in Bcr-Abl positive cells $[34,35]$. Synergy was also observed when HHT and imatinib were used in combination against imatinibresistant cell lines and against primary blastic cells obtained from patients with advanced phase CML (CML-AP) [36]. HHT does not compete with ATP at the catalytic domain of the Bcr-abl kinase; therefore, it is conceivable that the activity of HHT against Bcr-Abl positive cells is independent of their Bcr-Abl mutational status. In fact, in vitro data have demonstrated that the activity of HHT against Bcr-Abl positive cells was similar irrespective of whether the cells harbored non-mutated Bcr-Abl or the imatinib-resistant E255K or T315I mutations [19]. These studies raise the possibility that the efficacy of current CML therapy with TKIs may be increased by combined treatment with HHT and omacetaxine.

Leukemia initiating cells (LICs) are a population of stem cells that are capable of tumor initiation and maintenance of the disease. LICs in CML are thought to reside in a population of Bcr-Abl positive cells with characteristics of hematopoietic stem cells. Current TKIs do not kill these cells at a high frequency, but rather cause apoptosis in more differentiated Bcr-Abl positive cells of myeloid and lymphoid lineages [37]. In recent years, many studies have shown that HHT and omacetaxine could effectively kill Bcr-Abl positive LICs in vitro and in a mouse model of CML. The reason why HHT and omacetaxine target BcrAbl positive LICs may be that Bcr-Abl positive LICs require expression of certain short-lived proteins (e.g. Mcl-1, $\beta$-Catenin and the $\beta$ subunit of IL-3R). These proteins are preferentially lost to induce apoptosis and impair the renewal of Bcr-Abl positive LICs after treatment with HHT or omacetaxine [35,38-41]. A recent study by Shen et al. showed HHT could effectively kill the LICs in the human AML cell line KG1 by inhibiting cell growth and inducing apoptosis, which was associated with activation of the caspase pathway and downregulation of anti-apoptotic protein Bcl-2 and phosphorylated-Akt [42].

\section{HHT clinical development in CML}

The initial clinical trials of cephalotaxine esters in patients with cancer were conducted in the 1970s [1,5-7]. Nine of 15 patients with CML treated with HHT $\left(5 \mathrm{mg} \mathrm{d}^{-1} \sim 7 \mathrm{mg} \mathrm{d}^{-1}\right.$ for $7 \sim 10$ days) achieved complete hematological remission (CHR) [7]. In a subsequent study, 39\% (32 of 82) of CML patients treated with HHT (intravenously, $4 \mathrm{mg} \mathrm{d}^{-1}$ to $8 \mathrm{mg} \mathrm{d}^{-1}$ ) achieved CHR [10]. Huang et al. reported that $57.6 \%$ of 33 CML-CP patients treated with harringtonine (intravenously, $4 \mathrm{mg} \mathrm{d}^{-1}$, dose reduction and length of the course according the WBC counts) during 1991 1995 achieved CR [43]. In a study carried out during 1996 2002, 76 newly-diagnosed CML-CP patients were treated with HHT (intravenously, $1.5 \mathrm{mg} \mathrm{m}^{-2}$ daily for $7 \sim 11 \mathrm{~d}$ every month). Among 55 patients with cytogenetic data, $38.2 \%$ achieved CyR (cytogenetic response) and 20\% achieved MCR (major cytogenetic response), while only 2 of 10 patients with cytogenetic data achieved minor cytogenetic response in the group treated with hydroxyurea. The estimated 4-year overall survival (OS) was 46.2\%, which was significantly higher than that of the group treated with hydroxyurea $(27 \%, 10 / 27)$ [44]. In 2008, Li et al. reported a low-dose and long term protocol of HHT (intravenously or intramuscularly, $1 \mathrm{mg} \mathrm{d}^{-1}$ for 8 weeks or $2 \mathrm{mg} \mathrm{d}^{-1}$ for 4 weeks, next cycle beginning after 4-5 weeks interval until 4 years), which resulted in a CHR of $66 \%$ (27 of 41) and with 5-year progression-free survival rate (PFS) $95 \%$ (39 of 41) [45].

The first two phase I studies performed in the United States was published in 1983 and 1984, in which, a highly purified form of HHT was administered daily for 1 to 10 days, with dose escalation from $0.2 \mathrm{mg} \mathrm{m}^{-2}$ to $8 \mathrm{mg} \mathrm{m}^{-2}$ daily. Cardiovascular collapse (hypotension and tachycardia) happened in approximately $25 \%$ of patients who received HHT at doses of $5 \mathrm{mg} \mathrm{m}^{-2}$ or $6 \mathrm{mg} \mathrm{m}^{-2}$ daily, which were occasionally fatal. The short infusion maximum tolerated dose (MTD) was $<3 \mathrm{mg} \mathrm{m}^{-2}$ to $4 \mathrm{mg} \mathrm{m}^{-2}$ intravenously over 1 hour daily for 5 consecutive days $[8,46]$. About 10 years later, a study performed by O'Brien et al. showed encouraging results. HHT was given as a single agent to 71 patients with late CML-CP at a dose of $2.5 \mathrm{mg} \mathrm{m}^{-2}$ daily for 14 days during the remission induction phase and for 7 days monthly during the maintenance phase. Seventy-two percent of 58 assessable patients achieved CHR and 31\% of 71 patients achieved a CyR, including 15\% MCyR and 7\% complete cytogenetic response (CCyR). The major toxicities were myelosuppression which occurred in 39\% of induction courses [11].

Subsequently, HHT was administered to 99 patients with early CML-CP using a dose schedule similar to that 
of the previous study of O'Brien et al., for six cycles, followed by the administration of IFN-a maintenance. The results showed that the rates of $\mathrm{CHR}, \mathrm{CyR}$ and $\mathrm{MCyR}$ were $92 \%, 60 \%$ and $27 \%$, respectively, which were superior to those in historic control patients after 6 months of IFN-a therapy [11]. In another study performed by Kantarjian et al., the combination of HHT and low-dose ara-C was used to treat 100 patients in late CML-CP who had failed on IFN-a therapy. Seventy-two percent of patients achieved CHR, and 32\% achieved CyR, including 15\% MCyR and $5 \%$ CCyR [47]. In a phase II study reported by Stone et al., the combination of HHT (2.5 $\mathrm{mg} \mathrm{m}^{-2}$ daily) and ara-C (7.5 $\mathrm{mg} \mathrm{m}^{-2}$ daily), given by continuous intravenous infusion for 7 days every 28 days, was administrated to 44 patients with newly-diagnosed CML-CP. The results showed an $82 \%$ CHR and a $17 \%$ MCyR [48]. Moreover, O'Brien et al. treated 90 patients in early CML-CP with the triple combination of HHT, IFN-a, and low-dose ara-C, which yielded a $94 \% \mathrm{CHR}$ and a $74 \% \mathrm{CyR}$, including $22 \% \mathrm{CCyR}$. After a median follow-up of 46 months, the estimated 5year OS rate was $88 \%$, and only $9 \%$ patients had progressed to CML-BP [49]. In China, He et al. treated seven CML$\mathrm{CP}$ patients with the combination HHT and AS2O3 $\left(10 \mathrm{mg} \mathrm{d}^{-1}\right.$ for $2 \sim 3$ weeks, HHT $3 \sim 4 \mathrm{mg} \mathrm{d}^{-1}$ for $1 \sim 2$ weeks). After the first course treatment, four patients achieved CHR [50]. These studies suggest that HHTbased combination therapy results in improved clinical outcomes compared with single-agent HHT in patients with CML-CP.

The striking results obtained by TKIs impaired the development of HHT in CML. However, the distinct mechanisms of action and the remarkable effects of HHT on Bcr-Abl positive LICs and imatinib-resistant Bcr-Abl mutants (including T315I) in vitro, led to the return of HHT to CML therapy. Notably, the T315I BcrAbl mutation does not respond to any approved TKI in vitro or clinically, except ponatinib which was approved by US FDA more recently [51]. The prognosis for chronic-phase CML patients with this mutation is poor. In a Phase I/II study, patients with CML who had achieved CyR but achieved a plateau in Bcr-Abl transcripts after treatment with imatinib for at least 2 years were given omacetaxine $\left(1.25 \mathrm{mg} \mathrm{m}^{-2}\right.$ twice daily for $1-$ 3 days every 28 days). Of 10 evaluable patients, seven patients, including two with the Bcr-Abl mutation, had an appreciable decline in Bcr-Abl transcript levels. The results suggested the addition of omacetaxine should be considered for patients on imatinib who fail to obtain low levels of minimal residual disease [52]. In another Phase I/II study, six imatinib-resistant CML patients, including two patients with Bcr-Abl mutations, were treated with omacetaxine alone $\left(2.5 \mathrm{mg} \mathrm{m}^{-2}\right.$ intravenously over 24 hours, followed by $1.25 \mathrm{mg} \mathrm{m}^{-2}$, subcutaneously, twice a day, for 14 days in inducing period and for 7 days in maintenance period every month). CHR was obtained in all five evaluable patients and three had $\mathrm{CyR}$, including one with $\mathrm{CCyR}$. The Bcr-Abl mutations in both instances became undetectable [53]. In 2007, Legros et al. reported that Bcr-Abl (T315I) transcript disappeared in an imatinib-resistant CML patient treated with omacetaxine for the first time [54]. A study performed by Nicolini et al. investigated the effects of omacetaxine on non-mutated and T315I-mutated Bcr-Abl transcripts in eight TKI-resistant CML-CP patients. An initial rapid decline and a sustained disappearance of T315I-mutated transcripts were observed in 50\% of the patients. As the non-mutated leukemic burden reduction was modest, two patients were submitted to nilotinib after 9 months of sustained Bcr-Abl T315I transcripts negativity on omacetaxine: the mutated transcripts remained undetectable after a median follow-up of 12 months on nilotinib challenge [55]. In a recently reported phase II study, the efficacy of omacetaxine in CML-CP patients with T315I after TKI failure was assessed. Patients received omacetaxine $1.25 \mathrm{mg} \mathrm{m}^{-2}$ twice daily for 14 days every 28 days in induction period and for 7 days every 28 days in maintenance period. Seventy-seven percent of 62 patients achieved CHR, 23\% achieved MCyR, including 16\% with CCyR [56]. These results suggested that HHT and omacetaxine might provide an effective treatment for CML patients with the T315I mutation. HHT and omacetaxine (a non-targeted therapy) might provide better disease control, allowing the disappearance of the mutated clone, probably elicited by the clone deselection after TKI release, and could allow for a safe TKI rechallenge in patients with resistant CML-CP. In consideration of the effect of HHT and omacetaxine on the LICs, the combination treatment of HHT or omacetaxine with IM in newly diagnosed CML may provide an approach to cure the disease and reduce the risk of relapse after the termination of IM treatment.

\section{HHT clinical development in AML}

After the initial clinical trials of harringtonine and HHT in leukemia patients [1,5-7], harringtonine and HHT was widely used in China to treat patients with AML. For example, in 1989, Wang et al. reported the $40 \%(8 / 20)$ of patients with AML (16 newly-diagnosed, 4 relapsed, $20 \sim 76$ years old) achieved CR after induction of low-dose harringtonine $\left(0.6 \sim 1 \mathrm{mg} \mathrm{d}^{-1}\right.$ for 20 days or until CR or until severe adverse reaction) [57]. At the same time, Huang et al. reported a $75 \%(12 / 16)$ CR rate of AML patients treated with low-dose HA regimen (HHT $1 \sim 2 \mathrm{mg} \mathrm{d}^{-1}$, Ara-c $7.5 \sim 15 \mathrm{mg} 12 \mathrm{~h}^{-1}$ until CR or severe myelosuppression) [58]. These promising results encouraged a series of studies of a 7-day HA induction regimen for the treatment of AML. For example, Zheng et al. treated 34 AML patients (31 newly diagnosed and 3 relapsed) with HA 
regimen (harringtonine $3 \mathrm{mg} \mathrm{d}^{-1}$, for 3 days, Ara-c $150 \sim$ $200 \mathrm{mg} \mathrm{d}^{-1}$ for 7 days, intravenously) from 1986 to 1988 , the CR rate was $70.6 \%$ [12]. In a random control study for newly-diagnosed AML patients performed by Bian et al., the $\mathrm{CR}$ rate of the $\mathrm{HA}$ regimen (HHT $3 \sim 6 \mathrm{mg} \mathrm{d}^{-1}$ for 7 days, Ara-c $100 \sim 300 \mathrm{mg} \mathrm{d}^{-1}$ for 7 days) was $60.7 \%$ (51/84) and that of DA (daunorubicin (DNR) $40 \sim 80 \mathrm{mg} \mathrm{d}^{-1}$ for 3 days, Ara-c $100 \sim 300 \mathrm{mg} \mathrm{d}^{-1}$ for 7 days) regimen was $68.9 \%$ (40/58). After several regimens alternate consolidate therapy, the 5-year OS rates of the HA group and the DA group were $32 \%$ and $28 \%$, respectively. The differences of near-term CR rates and long-time OS rates were not significant between the HA regimen and the DA regimen [59]. In the study performed by Fu et al., the CR rates of newly-diagnosed AML patients treated with the HA regimen (HHT $2 \sim 4 \mathrm{mg} \mathrm{d}^{-1}$ for 5-7 days, Ara-c $100 \sim$ $200 \mathrm{mg} \mathrm{d}^{-1}$ for 7 days) and the DA regimen (DNR $40 \sim$ $60 \mathrm{mg} \mathrm{d}^{-1}$ for 3 days, Ara-c $100 \sim 200 \mathrm{mg} \mathrm{d}^{-1}$ for 7 days) were comparable $(73.14 \%, 30 / 41$ vs. $78.46 \%, 51 / 65)$ [60]. In the study of Yang et al., 56 newly diagnosed AML patients randomly received $\mathrm{HA}$ or DA treatment. The CR rates in the HA group (63.6\%) and the DA group (67.6\%) were also similar. The adverse reactions to HA were relatively mild [61]. Though lacking data of multiple-centre, random, controlled study, these studies could suggest that HA is an effective induction regimen, comparable with DA regimen, for AML patients (Table 1). HHT was also well tolerated and did not cause more serious adverse events than DNR in the induction of AML (Table 2).

Subsequent studies also showed that an HHT based triple drug combination was highly effective in the treatment of AML. Xue et al. treated adult AML patients (newly diagnosed 38, relapse or refractory 12 ) with an HAD combination regimen (HHT $4 \mathrm{mg} \mathrm{d}^{-1}$, for 7 days, DNR $60 \mathrm{mg} \mathrm{d}^{-1}$ for 3 days, Ara-c $200 \mathrm{mg} \mathrm{d}^{-1}$ for 7 days). The result showed that the CR rate was as high as $86.0 \%$ $(43 / 50)$, while the treatment related mortality (TRM) was only 4\% [62]. Xiao and colleagues showed that in 72 young untreated patients, this HAD regimen resulted in a CR rate of $86.1 \%$, and a 3 -year OS rate of $55.9 \%$ [63]. In 1997, Wan reported an HAA regimen (HHT $3 \mathrm{mg} \mathrm{d}^{-1}$, for 3 days; Ara-c $200 \mathrm{mg} \mathrm{d}^{-1}$, for 7 days; aclarubicin $20 \mathrm{mg} \mathrm{d}^{-1}$, for 3 days) in the treatment of AML patients (20 newly diagnosed, five refractory or relapsed) and the CR rate was 76.0\% [64]. The efficacy of the HAA regimen in the treatment of young (14-60 years old) de novo AML patients was confirmed in studies performed by Jin and colleagues $[65,66]$. The encouraging results led to an openlabel, random, controlled, phase III study in 17 institutions in China [67]. The results showed $73 \%$ of patients (150/ 206) with AML (non-acute promyelocytic leukemia (APL)) in the HAA (HHT $2 \mathrm{mg} \mathrm{m}^{-2} \mathrm{~d}^{-1}$ for 7 days, Ara-c $100 \mathrm{mg} \mathrm{m}^{-2} \mathrm{~d}^{-1}$ for 7 days, and aclarubicin $20 \mathrm{mg} \mathrm{d}^{-1}$ for 7 days) group achieved CR, which was significantly higher than that in the DA (DNR 40-45 $\mathrm{mg} \mathrm{m}^{-2} \mathrm{~d}^{-1}$ for 3 days and Ara-c $100 \mathrm{mg} \mathrm{m}^{-2} \mathrm{~d}^{-1}$ for 7 days) group (61\%, 125/205). Patients in CR were offered two cycles of intermediate-dose Ara-c ( $2 \mathrm{~g} \mathrm{~m}^{-2}$ every $12 \mathrm{~h}$ for 3 days). A $35.4 \%$ of 3 -year event-free survival was observed in the HAA group versus $23.1 \%$ in the DA group. These results suggested an HHT-based triple drug combination, especially the HAA regimen, is a treatment option for young, newly diagnosed patients with AML (Table 1).

HHT was also used in the treatment of patients with APL. In 1992, Xu et al. administrated all-trans-retinoic acid (ATRA) and low-dose HHT $\left(1 \mathrm{mg} \mathrm{d}^{-1}\right.$ for 10 days, interval 5-7 days to next cycle) to 25 patients with APL and the CR rate was 92\% [68]. In the study of Liu et al., thirty-five patients with APL were treated with ATRA and low-dose HHT $\left(0.5 \sim 1 \mathrm{mg} \mathrm{d}^{-1}\right)$ was added when $\mathrm{WBC}>\left(5 \sim 10 \times 10^{9} / \mathrm{L}\right)$ until $\mathrm{WBC}<4 \times 10^{9} / \mathrm{L}$. The adverse effects related to ATRA were significantly reduced [69]. Studies of Lin et al. and Cao et al. concerning ATRA and AS2O3 treatment of patients with APL

Table 1 The summary of studies of homoharringtonine-based regimens in the induction of acute myeloid leukemia

\begin{tabular}{|c|c|c|c|c|}
\hline Reference & Regimen & Patients no. & CR, \% & 3-year OS, \% \\
\hline Huang 1989 [58] & Low dose HHT + low Ara-c & 16 & 75.0 & NP \\
\hline Zheng 1989 [12] & $\mathrm{HHT}+\mathrm{Ara}-\mathrm{C}$ & 34 & 70.6 & NP \\
\hline Bian 1993 [59] & $\mathrm{HHT}+$ Ara-c & 84 & 60.7 & 32 (5-year OS) \\
\hline Fu 2001 [60] & $\mathrm{HHT}+\mathrm{Ara}-\mathrm{C}$ & 41 & 73.1 & NP \\
\hline Yang 2005 [61] & $\mathrm{HHT}+\mathrm{Ara}-\mathrm{C}$ & 56 & 63.6 & NP \\
\hline Xue 1995 [62] & $\mathrm{HHT}+\mathrm{Ara}-\mathrm{C}+\mathrm{DNR}$ & 50 & 86.0 & NP \\
\hline Xiao 2008 [63] & $\mathrm{HHT}+\mathrm{Ara}-\mathrm{C}+\mathrm{DNR}$ & 72 & 86.1 & 55.9 \\
\hline Jin 2013 [67] & $\mathrm{HHT}+\mathrm{Ara}-\mathrm{C}+\mathrm{DNR}$ & 198 & 67.0 & 48.0 \\
\hline Wan 1997 [64] & $\mathrm{HHT}+$ Ara-c + aclarubicin & 25 & 76.0 & NP \\
\hline Song 2011 [66] & $\mathrm{HHT}+$ Ara-c + aclarubicin & 150 & 81.0 & 45.0 \\
\hline Jin 2013 [67] & $\mathrm{HHT}+$ Ara-c + aclarubicin & 206 & 73.0 & 48.5 \\
\hline
\end{tabular}

HHT homoharringtonine, Ara-c arabinoside, CR complete remission, OS overall survival, NP not provided. 
Table 2 Comparison of the toxicity of homoharringtonine and daunorubicin in the induction of acute myeloid leukemia

\begin{tabular}{ccccc}
\hline Reference & Rigemen (NO.) & Infection (\%) & Damage of liver function (\%) & Cardiotoxicity (\%) \\
\hline Yang 2005 [61] & DA(34) & 44.4 & 13.9 & 8.8 \\
Yuan 2011 [72] & HA(22) & 36.4 & 8.8 & 0 \\
& DNR + ATRA(61) & 67.2 & 14.8 & 0 \\
\hline
\end{tabular}

$D A$ daunorubicin + arabinoside, $H A$ homoharringtonine + arabinoside, DNR daunorubicin, $H T T$ homoharringtonine.

confirmed that the addition of HHT could shorten the time to CR and reduce the leukocyte stasis [70,71]. Yuan et al. evaluated the therapeutic effect of HHT plus ATRA by comparing with DNR plus ATRA as an induction regimen (HA or DA as post- remission consolidation regimen) in 115 cases (54 in the HHT group and 61 in the DNR group) of APL. The results showed that after induction therapy, $31.3 \%$ and $15.5 \%$ of patients in the HHT and DNR groups, respectively, were converted to PML-RAR $\alpha$ negative status detected with RT-PCR. No statistically significant difference was found on OS and EFS between the HHT group and the DNR group. This study demonstrated a comparable therapeutic effect of HHT and DNR on APL. HHT was also well tolerated and did not cause more serious adverse events than DNR [72] (Table 2). A recent study by Pei et al. showed that HHT in combination with ATRA and AS2O3 for newly diagnosed APL has a better efficacy, higher longterm survival and lower costs than idarubicine in combination with ATRA and AS2O3 [73]. Attractively, Liu et al. evaluated the cardiotoxicity of HHT and DNR in the treatment of APL when combined with ATRA in a single-centre, random, controlled study. The results showed HHT and DNR displayed similar cardiotoxicity, mainly ST-T changes and left-ventricular fractional decrease in some patients [74] (Table 3).

HHT-based regimens were also effective to patients with relapsed and refractory AML. In a study performed by Fu et al., 27 AML patients who were NR or relapsed after DA treatment received HA treatment; 16 (59.25\%) of them obtained CR. The results suggested HHT was active in the treatment of relapsed and refractory AML and there was no cross resistance between HHT and DNR [60]. Meng et al. treated 24 patients with refractory AML by a regimen combining HA with etoposide or teniposide, and $80 \%$ patients achieved CR [75]. Sensitization of leukemic cells with granulocyte colony-stimulating factor (G-CSF) can enhance the cytotoxicity of chemotherapy in AML. Therefore, many studies have been conducted to evaluate the effect of G-CSF priming combined with low-dose HA chemotherapy (HAG regimen) in patients with relapsed and refractory AML. In a study performed by Wei et al., the HAG regimen (G-CSF $200 \mu \mathrm{g} \mathrm{m}^{-2}$, beginning from one day prior to chemotherapy until WBC $>20 \times 10^{9} \mathrm{~L}^{-1}$ for $14 \sim 28 \mathrm{~d}$, Ara-C $10 \mathrm{mg} \mathrm{m}^{-2}, 1 / 12 \mathrm{~h}$, for $14 \sim 28 \mathrm{~d}$, HHT $1 \sim 2 \mathrm{mg} \mathrm{m}^{-2}$ for $14 \sim 28 \mathrm{~d}$ ) was used to treat 20 refractory AML patients, which resulted in a CR rate of $70 \%$ [76]. In another study, 36 AML patients (23 refractory and 13 relapsed) were treated with the similar HAG regimen (Ara-c $7.5 \mathrm{mg} \mathrm{m}^{-2} 12 \mathrm{hr}^{-1}$ on days $1 \sim 14$, HHT $1.5 \mathrm{mg} \mathrm{m}^{-2}$ on days $1 \sim 14$, and G-CSF150 $\mu \mathrm{g} \mathrm{m}^{-2}$ on days $0 \sim 14)$. Fifty percent of patients achieved CR with a median CR duration of 7.2 months [77]. In some similar studies reported, the CR rates of the HAG regimen varied from $43 \%$ to $52.2 \%$ in relapsed, refractory or hypocellular AML, the TRM of HAG regimen is low $[78,79]$. These studies suggested that the HAG regimen is highly effective for refractory or relapsed AML patients without severe side effects (Table 4).

The efficacy of priming HAG chemotherapy was also widely evaluated in elderly patients with AML. In a study performed by Liu et al., 31 elderly AML patients (aged 57-72) were treated with the HAG regimen (G-CSF $200 \mu \mathrm{g} \mathrm{m}^{-2}$, on days $1-14$, HHT $\operatorname{lmg~\mathrm {m}^{-2}}$ on days $1-14$, Ara-C $10 \mathrm{mg} \mathrm{m}^{-2}, 1 / 12 \mathrm{~h}$, on days $1-14$ ), resulting in a CR rate of $58.1 \%$ and an OR rate of $80.6 \%$, which were significantly higher than those (CR $32.4 \%$; OR 55.9\%) in the HA group (HHT $4 \mathrm{mg}$, on days $1-7$, Ara-c $100 \mathrm{mg} \mathrm{m}^{-2}$, on days 1-7). The myelosuppression of the HAG regimen was milder than the HA regimen [80] (Table 4).

In the USA, a phase I trial conducted by Feldman et al. confirmed the HHT $4 \mathrm{mg} \mathrm{m}^{-2}$ for 7 days by continuous

Table 3 Comparison of the cardiotoxicitv of homoharringtonine and daunorubicin in adults with acute promyelocytic leukemia

\begin{tabular}{ccccccc}
\hline Reference & $\begin{array}{c}\text { Accumulative dose } \\
\left(\mathbf{m g}^{-2} \mathbf{)}\right.\end{array}$ & $\begin{array}{c}\text { Total } \\
(\mathbf{n})\end{array}$ & $\begin{array}{c}\text { Change of ST-T } \\
(\mathbf{n})\end{array}$ & $\begin{array}{c}\text { Nodal tachycardia } \\
(\mathbf{n})\end{array}$ & $\begin{array}{c}\text { Decrease of LVEF }>\mathbf{1 0} \% \\
(\mathbf{n})\end{array}$ & $\begin{array}{c}\text { Increase of myocardial } \\
\text { enzyme (n) }\end{array}$ \\
\hline Liu 2012 & HHT(44) & 27 & 3 & 4 & 8 & 0 \\
[74] & DNR(405) & 28 & 5 & 5 & 7 & 0
\end{tabular}

DNR daunorubicin, $H T T$ homoharringtonine, LVEF left ventricular ejection fraction. 
Table 4 The summary of studies of HAG regimen for AML, high-risk MDS and MDS/AML

\begin{tabular}{llll}
\hline Reference & Patients type & No. & CR, \% \\
\hline Wei 2006 [76] & Refractory or relapsed AML & 20 & 70.0 \\
Zhang 2008 [77] & Refractory or relapsed AML & 36 & 50.0 \\
Ji 2010 [78] & Refractory or relapsed AML & 37 & 46.0 \\
Gu 2011 [79] & Refractory or relapsed AML & 67 & 52.2 \\
Liu 2006 [80] & Elderly AML & 31 & 58.1 \\
Shu 2007 [84] & MDS-RAEB & 28 & 53.6 \\
Su 2008 [85] & High-risk MDS or MDS/AML & 33 & 46.7 \\
Wu 2009 [86] & High-risk MDS or MDS/AML & 32 & 46.9 \\
Wu 2011 [87] & Elderly high-risk MDS or MDS/AML & 33 & 57.6 \\
\hline
\end{tabular}

HAG homoharringtonine + arabinoside + G-CSF, CR complete remission, $A M L$ acute myeloid leukemia, MDS myelodysplastic syndrome. $M D S / A M L$ MDS evolving to AML.

infusion in combination with Ara-c is safe and effective for patients with AML [81]. However, there was no further related report after this trial in the USA and clinical data of omacetaxine in the treatment of AML is still absent. To fully estimate the effect and toxicity of HHT and omacetaxine compared with DNR in the treatment of AML, especially to compare HA regimen with standard DA regimen, multiple-centre, randomized, controlled phase III trials are required.

\section{HHT clinical development in high-risk MDS or MDS evolving to AML (MDS/AML)}

In China, harringtonine and HHT were also widely used to treat patients with high-risk MDS or MDS/AML. Cao et al. treated patients of MDS-RAEB or MDS/AML with low-dose harringtonine $(0.5 \sim 1 \mathrm{mg}$, intravenously, daily or once every two days, for $10 \sim 15$ days, with an interval of $5 \sim 10$ days between the two cycles) during 19841989, CR was achieved in 4 of 13 patients [13]. Subsequently, Ji et al. reported a 50\% (7/14) CR rate in patients with MDS-RAEB or MDS/AML treated with low-dose harringtonine $\left(0.5 \sim 1 \mathrm{mg} \mathrm{d}^{-1}\right.$, intravenously, for $10 \sim 15$ days, with an interval of $7 \sim 10$ days between the two cycles) [82]. In a phase II trial in the USA reported by Feldman et al., HHT was administered at a dose of $5 \mathrm{mg} \mathrm{m}^{-2}$ by 24-h continuous infusion daily for 9 days to patients with MDS or MDS/AML. CR was achieved in seven patients, and the OR rate was $28 \%$ $(8 / 28)$. Significant myelosuppression was universal and resulted in a high incidence of induction deaths (13/28) caused by neutropenia-related infections [83].

The priming HAG regimen that was highly effective for refractory or relapsed AML was also widely used to treat high-risk MDS or MDS/AML (Table 4). In a study by Shu et al., 28 MDS-RAEB patients were treated with the HAG regimen, which resulted in a CR rate of $53.6 \%$ [84]. Similarly, Su et al. reported that $46.67 \%$ of 33 newly diagnosed patients with high-risk MDS or MDS/AML treated with one course of HAG as induction chemotherapy achieved CR, while the CR rate in the group of HA regimen was $33.3 \%$. The difference was statistically significant between the two groups [85]. Meanwhile, Wu et al. reported a $46.9 \% \mathrm{CR}$ rate in 32 patients with advanced MDS or MDS/AML after one course of HAG therapy [86]. Wu et al. also evaluated the efficacy and toxicity of the HAG regimen as induction chemotherapy for elderly patients with high-risk MDS or MDS/AML. The CR rate was $57.6 \%$ (19/33). The median OS was 15 months. Grade 3/4 thrombocytopenia occurred in $28 \%$ patients and neutropenia in 34\%. No treatment-related deaths occurred during the induction therapy. The data suggest that the HAG priming regimen is effective and safe as an induction therapy for patients, including elderly patients, with high-risk MDS and MDS/AML [87]. These studies also suggested that stronger and alternative subsequent chemotherapy is necessary for patients achieved CR to maintain longer CR duration and better OS [84-87].

These data of HHT in the treatment high-risk MDS and MDS/AML were generally scattered and retrospective. So multiple-center prospective randomized trials are also needed to evaluate the effect and toxicity of HHT (or omacetaxine)-based regimens, especially HAG regimen in the treatment of high-risk MDS and MDS/AML.

\section{Summary}

HHT, a plant alkaloid with antitumor properties originally identified nearly 40 years ago, has a unique mechanism of action compared with other antitumor drugs. HHT inhibits protein synthesis by competing with the amino acid side chains of incoming aminoacyl-tRNAs for binding to the A-site cleft in the peptidyl transferase center of the ribosome. HHT induces the rapid loss of a number of short-lived proteins regulating proliferation and cell survival of various cell lines from hematological malignancies, which triggers HHT-induced apoptosis. In addition, sHHT (omacetaxine) caused less damage to the environment and another potential advantage is its excellent bioavailability by the SC route, which provides patients with the opportunity to self-administer their therapy. Preclinical studies have proved the synergistic effect of HHT with other agents, such as IFN-a, Ara-C and imatinib. Data from preclinical studies also showed the remarkable effects of HHT and omacetaxine on LICs and imatinib-resistant Bcr-Abl mutants (including T315I). Clinical studies suggested that HHT is effective for patients with CML-CP, and HHT-based combination can improve clinical outcomes. Clinical studies also suggested that HHT and omacetaxine may provide an effective treatment for TKIs-resistant CML patients with Bcr-Abl mutations, including T315I, and could allow a safe TKIs 
rechallenge. Many studies in China showed that HHTbased combination therapy is highly effective in the treatment of young, newly diagnosed AML, with at least comparable results with that of DA regimen. Clinical studies also showed that HHT-based regimens, especially the HAG priming regimen, are well tolerated and effective in patients with relapsed and refractory AML, high-risk MDS, MDS/AML or elderly patients with AML. The main adverse effects of HHT in the treatment of AML and MDS were myelosuppression and cardiotoxicity which were at least not more severe than DNR. But HHT was rarely used for the treatment of AML and MDS outside of China and there were also no clinical data of omacetaxine in the treatment of AML and MDS up to date.

Further studies should assess the suitability of combining HHT with TKIs and/or other agents in an attempt to improve current salvage regimens for patients with CML. In order to avoid Bcr-Abl mutating and cure the disease by killing LICs, clinical trials of the combination of HHT or HHT analogs with TKIs in the treatment of patients with newly diagnosed CML are also deserve to carry out. Studies should be performed to expand and validate the experiences of HHT in the treatment of AML and MDS in China with multiple-center prospective randomized trials.

The generation of HHT analogs with improved toxicity profiles and perhaps with oral bioavailabity should also be explored [88].

\section{Competing interests}

The authors declare that they have no competing interests.

\section{Authors' contributions}

Both authors read and approved the final manuscript.

\section{Acknowledgements}

This work is supported in part by grants from the National Natural Science Foundation of China (No. 81090413, 81270638) to J.W. and (No. 30873042, 81100361) to S.L.

Received: 8 November 2013 Accepted: 26 December 2013 Published: 3 January 2014

\section{References}

1. Cooperative Study Group of Zhe Jiang province for Cephalotaxus fortune Hook: Clinical studies of alkaloids from cephalotaxus fortune Hook. Zhe Jiang Zhong Liu Tong Xun 1976, 2:14.

2. Paudler WW, Kerley GI, McKay J: The alkaloids of cephalotaxus drupacea and cephalotaxusfortunei. J Org Chem 1963, 28:2194-2197.

3. Powell RG, Smith CR: Structure of cephalotaxine and related alkaloids. Tetrahedron Lett 1969, 46:4081-4084.

4. Powell RG, Weislede D, Smith CR: Antitumor alkaloids from cephalotaxus harringtonia: structure and activity. J Pharm Sci 1972, 61:1227-1230.

5. Shanghai Institute of Materia Medica, Shanghai Leukemia Coordinating Group, Provincial People's Hospital of Fukien and Chekiang Cephalotaxus Research Coordinating Group of China: Cephalotaxine esters in the treatment of acute leukemia. A preliminary clinical assessment. Chin Med J (Engl) 1976, 2:263-272.

6. Institute of Materia Medica, Chinese Academy of Medical Sciences: The antitumor effects and pharmacologic actions of harringtonine. Chinese Med J 1977, 3:319-324.
7. Chinese People's Liberation Army, 187th Hospital: Homoharringtonine in the treatment of leukemias: clinical analysis of 72 cases. Chinese Med J 1978, 3:163-166.

8. Legha SS, Keating M, Picket S, Ajani JA, Ewer M, Bodey GP: Phase I clinical investigation of homoharringtonine. Cancer Treat Rep 1984, 68:1085-1091.

9. Coonley CJ, Warrell RP Jr, Young CW: Phase I trial of homoharringtonine administered as a 5-day continuous infusion. Cancer Treat Rep 1983, 67:693-696.

10. Zhang $Z Y$, Hou CH, Zhu YF: A preliminary therapeutic analysis of 82 cases of chronic granulocytic leukemia treated with harringtonine. Chinese $J$ Intern Med 1986, 25:156-157. 190.

11. O'Brien S, Kantarjian H, Keating M, Beran M, Koller C, Robertson LE, Hester J, Rios MB, Andreeff M, Talpaz M: Homoharringtonine therapy induces responses in patients with chronic myelogenous leukemia in late chronic phase. Blood 1995, 86:3322-3326.

12. Zheng BG, Luo XS, Zhou YH, Zheng ZY, Shen YP, Lin SY, Hu ZP: The treatment of $\mathrm{HA}$ regimen in 34 patients with acute non-lymphocytic leukemia. Chin J Hematol 1989, 10:405-406.

13. Cao PS, Liu X: The treatment of harringtonine in 13 patients with myelodysplastic syndrome. Chin J Hematol 1990, 11:425.

14. Druker BJ, Tamura S, Buchdunger E, Ohno S, Segal GM, Fanning S, Zimmermann J, Lydon NB: Effects of a selective inhibitor of the Abl tyrosine kinase on the growth of Bcr-Abl positive cells. Nat Med 1996, 2:561-566.

15. Robin J, Dhal R, Dujardin G, Girodier L, Mevellec L, Poutot $S$ : The first semisynthesis of enantiopure homoharringtonine via anhydro homoharringtonine from a preformed chiral acyl moiety. Tetrahedron Lett 1999, 40:2931-2934.

16. Fresno M, Jiménez A, Vázquez D: Inhibition of translation in eukaryotic systems by harringtonine. Eur J Biochem 1977, 72:323-330.

17. Huang MT: Harringtonine, an inhibitor of initiation of protein biosynthesis. Mol Pharmacol 1975, 11:511-519.

18. Gurel G, Blaha G, Moore PB, Steitz TA: U2504 determines the species specificity of the A-site cleft antibiotics: the structures of tiamulin, homoharringtonine, and bruceantin bound to the ribosome. J Mol Biol 2009, 389:146-156.

19. Chen R, Gandhi V, Plunkett W: A sequential blockade strategy for the design of combination therapies to overcome oncogene addiction in chronic myelogenous leukemia. Cancer Res 2006, 66:10959-10966.

20. Kuroda J, Kamitsuji Y, Kimura S, Ashihara E, Kawata E, Nakagawa Y, Takeuichi M, Murotani Y, Yokota A, Tanaka R, Andreeff M, Taniwaki M, Maekawa T: Anti-myeloma effect of homoharringtonine with concomitant targeting of the myelomapromoting molecules, Mcl-1, XIAP, and beta-catenin. Int J Hematol 2008, 87:507-515.

21. Tang R, Faussat AM, Majdak P, Marzac C, Dubrulle S, Marjanovic Z, Legrand $\mathrm{O}$, Marie JP: Semisynthetic homoharringtonine induces apoptosis via inhibition of protein synthesis and triggers rapid myeloid cell leukemia-1 down-regulation in myeloid leukemia cells. Mol Cancer Ther 2006, 5:723-731.

22. Mai WY, Lin MF: Induction of apoptosis by homoharringtonine in G1 phase human chronic myeloid leukemic cells. Chin Med J (Engl) 2005, 118:487-492.

23. Kuroda J, Kimura S, Andreeff M, Ashihara E, Kamitsuji Y, Yokota A, Kawata E, Takeuchi M, Tanaka R, Murotani Y, Matsumoto Y, Tanaka H, Strasser A, Taniwaki M, Maekawa T: ABT-737 is a useful component of combinatory chemotherapies for chronic myeloid leukaemias with diverse drugresistance mechanisms. Br J Haematol 2008, 140:181-190.

24. Lou $Y$, Jin J, Xu W, Tong $X$ : Homoharringtonine mediates myeloid cell apoptosis via upregulation of pro-apoptotic bax and inducing caspase-3mediated cleavage of poly(ADP-ribose) polymerase (PARP). Am J Hematol 2004, 76:199-204.

25. Lin CJ, Cencic R, Mills JR, Robert F, Pelletier J: c-Myc and elF4F are components of a feed forward loop that links transcription and translation. Cancer Res 2008, 68:5326-5334. 5322.

26. Lin CJ, Malina A, Pelletier J: c-Myc and elF4F constitute a feed forward loop that regulates cell growth: implications for anticancer therapy. Cancer Res 2009, 69:7491-7494.

27. Cai Z, Bao HY, Ludwig WD, Wuchter C: Expression and significance of apoptosis protein inhibitor survivin and XIAP, in patients with myelodysplastic syndromes and in the cell line MUTZ-1. Chinese J Hematol 2004, 25:26-30.

28. Hu J, He D, Xue X, Gao L, Wu W, Han X, Cai Z: Homoharringtonineinduced apoptosis of MDS cell line MUTZ-1 cells is mediated by the endoplasmic reticulum stress pathway. Leuk Lymphoma 2007, 48:964-977. 
29. Tong H, Ren $Y$, Zhang F, Jin J: Homoharringtonine affects the JAK2-STAT5 signal pathway through alteration of protein tyrosine kinase phosphorylation in acute myeloid leukemia cells. Eur J Haematol 2008, 81:259-266.

30. Lucas DM, Edwards RB, Lozanski G, West DA, Shin JD, Vargo MA, Davis ME, Rozewski DM, Johnson AJ, Su BN, Goettl VM, Heerema NA, Lin TS, Lehman A, Zhang X, Jarjoura D, Newman DJ, Byrd JC, Kinghorn AD, Grever MR: The novel plant-derived agent silvestrol has B-cell selective activity in chronic lymphocytic leukemia and acute lymphoblastic leukemia in vitro and in vivo. Blood 2009, 113:4656-4666.

31. Alachkar H, Santhanam R, Harb JG, Lucas DM, Oaks JJ, Hickey CJ, Pan L, Kinghorn AD, Caligiuri MA, Perrotti D, Byrd JC, Garzon R, Grever MR, Marcucci G: Silvestrol exhibits significant in vivo and in vitro antileukemic activities and inhibits FLT3 and miR-155expressions in acute myeloid leukemia. J Hematol Oncol 2013, 6:21

32. Visani G, Russo D, Ottaviani E, Tosi P, Damiani D, Michelutti A, Manfroi S, Baccarani M, Tura S: Effects of homoharringtonine alone and in combination with alpha interferon and cytosine arabinoside on in vitro growth and induction of apoptosis in chronic myeloid leukemia and normal hematopoietic progenitors. Leukemia 1997, 11:624-628.

33. Branford S, Rudzki Z, Walsh S, Parkinson I, Grigg A, Szer J, Taylor K, Herrmann R, Seymour JF, Arthur C, Joske D, Lynch K, Hughes T: Detection of $B C R-A B L$ mutations in patients with $C M L$ treated with imatinib is virtually always accompanied by clinical resistance, and mutations in the ATP phosphate-binding loop (P-loop) are associated with a poor prognosis. Blood 2003, 102:276-283.

34. Wang H, Guo Z, Ji S: Homoharringtonine induces apoptosis of K562 cells through inhibition of P210bcr/abl. Zhongguo Shi Yan Xue Ye Xue Za Zhi 2000, 8:287-289.

35. Chen Y, Hu Y, Michaels S, Segal D, Brown D, Li S: Inhibitory effects of omacetaxine on leukemic stem cells and BCR-ABL induced chronic myeloid leukemia and acute lymphoblastic leukemia in mice. Leukemia 2009, 23:1446-1454.

36. Tipping AJ, Mahon FX, Zafirides G, Lagarde V, Goldman JM, Melo JV: Drug responses of imatinib mesylate-resistant cells: synergism of imatinib with other chemotherapeutic drugs. Leukemia 2002, 16:2349-2357.

37. Jorgensen HG, Holyoake TL: Characterization of cancer stem cells in chronic myeloid leukaemia. Biochem Soc Trans 2007, 35(Pt 5):1347-1351.

38. Allan EK, Holyoake TL, Craig AR, Jørgensen HG: Omacetaxine may have a role in chronic myeloid leukaemia eradication through downregulation of Mcl-1 and induction of apoptosis in stem/progenitor cells. Leukemia 2011, 25:985-994.

39. Zhao C, Blum J, Chen A, Kwon HY, Jung SH, Cook JM, Lagoo A, Reya T: Loss of beta-catenin impairs the renewal of normal and CML stem cells in vivo. Cancer Cell 2007, 12:528-541.

40. Hu Y, Chen Y, Douglas L, Li S: Beta-Catenin is essential for survival of leukemic stem cells insensitive to kinase inhibition in mice with BCR-ABL-induced chronic myeloid leukemia. Leukemia 2009, 23:109-116.

41. Klag T, Hartel N, Schenk T, Craig AR, Hochhaus A, Rosee PL: Downregulation of the common cytokine receptor subunit beta c by omacetaxine in CML: a potential molecular mechanism to overcome cytokine-mediated resistance against BCR-ABL-inhibitors. Blood 2009, 114:3256. Abs.

42. Shen JP, Yang H, Ni WM, Qian WB: Cytotoxicity of homoharringtonine on leukemic stem-like cells in AML cell line KG-1. Zhejiang Da Xue Xue Bao Yi Xue Ban 2012, 41:485-490.

43. Huang ZM, Chen M, Lü LH, Huang SH, Chen ZZ, Liang YY: A report of 33 cases of chronic granulocytic leukemia treated with harringtonine. Fu Jian Yi Ke Da Xue Xue Bao 1998, 32:383-384.

44. Li YF, Wang CL, Ding BH, Zhu JB, Zheng ST, Yu L, Qian MS: The long-term follow-up results of chronic granulocytic leukemia treated with homoharringtonine. Chin J Hematol 2004, 25:378-379.

45. $\mathrm{Li} \mathrm{CL}, \mathrm{Yu} \mathrm{XJ}$ : The long-term results of 41 cases with chronic granulocytic leukemia treated with homoharringtonine. Bai Xue Bing. Lin Ba Liu 2008, 17:142-143.

46. Neidhart JA, Young DC, Derocher D, Metz EN: Phase I trial of homoharringtonine. Cancer Treat Rep 1983, 67:801-804.

47. Kantarjian HM, Talpaz M, Smith TL, Cortes J, Giles FJ, Rios MB, Mallard S, Gajewski J, Murgo A, Cheson B, O'Brien S: Homoharringtonine and low-dose cytarabine in the management of late chronic-phase chronic myelogenous leukemia. J Clin Oncol 2000, 18:3513-3521.

48. Stone RM, Donohue KA, Stock W, Hars V, Linker CA, Shea T, Deangelo DJ, Marcucci G, Bloomfield CD, Larson RA, Cancer and Leukemia Group B: A phase II study of continuous infusion homoharringtonine and cytarabine in newly diagnosed patients with chronic myeloid leukemia: CALGB study 19804. Cancer Chemother Pharmacol 2009, 63:859-864.

49. O'Brien S, Giles F, Talpaz M, Cortes J, Rios MB, Shan J, Thomas D, Andreeff M, Kornblau S, Faderl S, Garcia-Manero G, White K, Mallard S, Freireich E, Kantarjian HM: Results of triple therapy with interferon-alpha, cytarabine, and homoharringtonine, and the impact of adding imatinib to the treatment sequence in patients with Philadelphia chromosome-positive chronic myelogenous leukemia in early chronic phase. Cancer 2003, 98:888-893.

50. He ZG, Hou $\sqcup, X u$ JB: The clinic study of therapy in the chronic myelocytic leukemia-chronic phase by $\mathrm{AS} 2 \mathrm{O} 3$ combined with homoharringtonine. $J$ Med Res 2008, 37:56-57.

51. Price KE, Saleem N, Lee G, Steinberg M: Potential of ponatinib to treat chronic myeloid leukemia and acute lymphoblastic leukemia. Onco Targets Ther 2013, 6:1111-1118.

52. Marin D, Kaeda JS, Andreasson C, Saunders SM, Bua M, Olavarria E, Goldman JM, Apperley JF: Phase I/II trial of adding semisynthetic homoharringtonine in chronic myeloid leukemia patients who have achieved partial or complete cytogenetic response on imatinib. Cancer 2005, 103:1850-1855.

53. Quintás-Cardama A, Kantarjian H, Garcia-Manero G, O'Brien S, Faderl S, Estrov Z, Giles F, Murgo A, Ladie N, Verstovsek S, Cortes J: Phase I/II study of subcutaneous homoharringtonine in patients with chronic myeloid leukemia who have failed prior therapy. Cancer 2007, 109:248-255.

54. Legros L, Hayette S, Nicolini FE, Raynaud S, Chabane K, Magaud JP, Cassuto $J P$, Michallet M: BCR-ABL (T315I) transcript disappearance in an imatinibresistant CML patient treated with homoharringtonine: a new therapeutic challenge? Leukemia 2007, 21:2204-2206.

55. Nicolini FE, Chomel JC, Roy L, Legros L, Chabane K, Ducastelle S, NicolasVirelizier E, Michallet M, Tigaud I, Magaud JP, Turhan A, Guilhot F, Hayette S: The durable clearance of the T315I BCR-ABL mutated clone in chronic phase chronic myelogenous leukemia patients on omacetaxine allows tyrosine kinase inhibitor rechallenge. Clin Lymphoma Myeloma Leuk 2010, 10:394-399.

56. Cortes J, Lipton JH, Rea D, Digumarti R, Chuah C, Nanda N, Benichou AC, Craig AR, Michallet M, Nicolini FE, Kantarjian H, Omacetaxine 202Study Group: Phase 2 study of subcutaneous omacetaxine mepesuccinate after TKI failure in patients with chronic-phase CML with T315I mutation. Blood 2012, 120:2573-2580.

57. Wang JM, Zhao ZY, Liu MX, Ju GD, Xu ZH, Zhang P: Clinical observation of low-dose harringtonine combination regimen in the treatment of acute non-lymphocytic leukemia. Chin J Hematol 1989, 10:137.

58. Huang $C L$, Qiao QD, Tao L: The effects observation of low-dose Ara-C and harringtonine combination regimen in the treatment of acute leukemia. Chin J Intern Med 1989, 28:239.

59. Bian SG, Hao YS, Wang ZC: Study of the treatment of adult acute nonlymphocytic leukemia. Chin J Hematol 1993, 14:59-62.

60. Fu YH, Liu YZ: 106 cases of acute myeloid leukemia treated with HA or DA regimen. Hu Nan Yi Xue 2001, 18:390.

61. Yang $M$, Chen $Q$, Chen $Y$, Pan HP: The effects comparison of homoharringtonine and daunorubicin in the treatment of 56 patients with acute myeloid leukemia. Acta Acad Med ZUNYI 2005, 28:345-346.

62. Xue YP, Bian SG, Meng QX, Mi YC, Yang DG: Clinical observation of HAD regien in adult acute myeloid leukemia treatment. Chin J Hematol 1995, 16:59-61.

63. Xiao Z, Xue H, Li R, Zhang L, Yu M, Hao Y: The prognostic significance of leukemic cells clearance kinetics evaluation during the initial course of induction therapy with HAD (homoharringtonine, cytosine arabinoside, daunorubicin) in patients with de novo acute myeloid leukemia. Am J Hematol 2008, 83:203-205.

64. Wan CC, Guo RC, Zhang ZH, Xia YJ: The efficacy observation of HAA regimen in acute myeloid leukemia. Lin Chuang Xue Ye Xue Za Zhi 1997, 10:92.

65. Jin J, Jiang DZ, Mai WY, Meng HT, Qian WB, Tong HY, Huang J, Mao LP, Tong $Y$, Wang L, Chen ZM, Xu WL: Homoharringtonine in combination with cytarabine and aclarubicin resulted in high complete remission rate after the first induction therapy in patients with de novo acute myeloid leukemia. Leukemia 2006, 20:1361. 136.

66. Song YP, Tong Y, Qian WB, Mai WY, Meng HT, Qian JJ, Tong HY, Huang J, Mao LP, Xu WL, Jin J: The efficacy and safety of HAA regimen as 
induction chemotherapy in 150 newly diagnosed acute myeloid leukemia. Chin J Intern Med 2011, 50:48-51.

67. Jin J, Wang JX, Chen FF, Wu DP, Hu J, Zhou JF, Hu JD, Wang JM, Li JY, Huang XJ, Ma J, Ji CY, Xu XP, Yu K, Ren HY, Zhou YH, Tong Y, Lou YJ, Ni WM, Tong HY, Wang HF, Mi YC, Du X, Chen BA, Shen Y, Chen Z, Chen SJ: Homoharringtonine-based induction regimens for patients with de-novo acute myeloid leukaemia: a multicentre, open-label, randomised, controlled phase 3 trial. Lancet Oncol 2013, 14:599-608.

68. Xu JM, Du Y, Zhang LL, Zhong WY, Xue LY: The treatment of alltransretinoic acid and low-dose homoharringtonine in acute promyelocytic leukemia. Shan Xi Bai Xue Bing 1992, 1:156-158.

69. Liu QC ZBR, Zhang FX, Guo LH, Ge XR: The combination of alltransretinoic acid and low-dose homoharringtonine in the treatment of acute promyelocytic leukemia. Chin J Intern Med 2000, 39:475-476.

70. Lin WQ, Zheng HY: The clinical analysis of all-transretinoic acid and As203 in combination with homoharringtonine for acute promyelocytic leukemia. China Prac Med 2009, 4:153-154.

71. Cao LP: The combination of arsenious acid, retinoic acid, homoharringtonine and cytarabine in the treatment of 20 cases with acute promyelocytic leukemia. Bai Xue Bing. Lin Ba Liu 2006, 15:291-292.

72. Yuan Y, Li W, Lin D, Mi YC, Wang Y, Wei H, Liu BC, Zhou CL, Liu KQ, Wang $J Y$, Wei SN, Gong BF, Zhao XL, Sun MY, Wang JX: Outcome of acute promyelocytic leukemia with homoharringtonine and ATRA. Chin J Hematol 2011, 32:752-757.

73. Pei RZ, Li SY, Zhang PS, Ma JX, Liu XH, Du XH, Chen D, Sha KY, Chen LG, Cao JJ, Zhuang XX, Wu JY, Lin L, Fan Z, Ye PP, Tang SH, Zhang BB, Shi XW: Clinical investigation of homoharringtonine in combination with alltransretinoic acid and arsenic trioxide for acute promyelocytic leukemia. Chin J Hematol 2013, 34:144-148.

74. Liu KQ, Wei H, Wang HJ, Zhou CL, Liu BC, Lin D, Li W, Wang JY, Wei SN, Gong BF, Zhang GJ, Zhao X, Zhao XL, Mi YC, Wang JX: Comparison of homoharringtonine and daunorubicin cardiotoxicitv in adults with acute promyelocytic leukemia. J Clin Med Pract 2012, 16:10-12. 17.

75. Meng FY, Xu B, Zhou SY: Treatment of HA combination with etoposide or VM-26 in high-risk and refractory adult acute myeloid leukemia. Bai Xue Bing 1999, 8:142-143.

76. Wei XD, Liu YY, Zhang LN, Wang P, Zhang YL, Zhu XH, Song YP: The comparison of efficiencies of $\mathrm{CHG}$ and CAG priming regimens in treatment of relapsed or fractory acute myeloid leukemia. Chin I Hematol 2006, 27:64

77. Zhang WG, Wang FX, Chen YX, Cao XM, He AL, Liu J, Ma XR, Zhao WH, Liu $\mathrm{SH}$, Wang JL: Combination chemotherapy with low-dose cytarabine, homoharringtonine, and granulocyte colony stimulating factor priming in patients with relapsed or refractory acute myeloid leukemia. Am J Hematol 2008, 83:185-188.

78. Ji YY, Zhang WG, Chen YX, Zhao XM, He AL, Liu J, Wang JL, Wang FX, Zhang PY, Zhang WJ: Efficiency of GHA priming therapy on patients with acute monocytic leukemia and its mechanism. Zhongguo Shi Yan Xue Ye Xue Za Zhi 2010, 18:213-218.

79. Gu LF, Zhang WG, Wang FX, Cao XM, Chen YX, He AL, Liu J, Ma XR: Low dose of homoharringtonine and cytarabine combined with granulocyte colony-stimulating factor priming on the outcome of relapsed or refractory acute myeloid leukemia. J Cancer Res Clin Oncol 2011, 137:997-1003.

80. Liu DB, Zhang YJ, Zhu XP, Xu WQ, Sun L, Luo YL: The comparison of efficiencies of $H A G$ and $H A$ regimens in treatment of elderly acute myeloid leukemia. Fu Jian Yi Ke Da Xue Xue Bao 2006, 40:274-276.

81. Feldman E, Arlin Z, Ahmed T, Mittelman A, Puccio C, Chun H, Cook P, Baskind $\mathrm{P}$ : Homoharringtonine in combination with cytarabine for patients with acute myelogenous leukemia. Leukemia 1992, 6:1189-1191.

82. Ji SY, Zhang F, Yang YL, Ding K: The treatment of low dose harringtonine in 14 patients with myelodysplastic syndrome. Ban Bu Yi Xue Yuan Xue Bao 1997, 22:253.

83. Feldman EJ, Seiter KP, Ahmed T, Baskind P, Arlin ZA: Homoharringtonine in patients with myelodysplastic syndrome (MDS) and MDS evolving to acute myeloid leukemia. Leukemia 1996, 10:40-42.

84. Shu HE, Li WG, Ge SB: Analysis of HAG regimen in the treatment of 28 patients with MDS-RAEB. Zhongguo Wu Zhen Xue Za Zhi 2007, 7:331-332.

85. Su JY, Chang CK, Zhang X, Zhou LY, Song LQ, Xu L, Wu LY, He Q, Li X: Efficacy of induction chemotherapy for patients with high-risk myelodysplastic syndrome (MDS) or MDS-transformed acute myeloid leukemia with $\mathrm{CHG}$ regimen and its comparison with regimen $\mathrm{GAG}$ and HA. Zhongquo Shi Yan Xue Ye Xue Za Zhi 2009, 17:459-463.

86. Wu L, Li X, Su J, Chang C, He Q, Zhang X, Xu L, Song L, Pu Q: Effect of low-dose cytarabine, homoharringtonine and granulocyte colonystimulating factor priming regimen on patients with advanced myelodysplastic syndrome or acute myeloid leukemia transformed from myelodysplastic syndrome. Leuk Lymphoma 2009, 50:1461-1467.

87. Wu L, Li X, Su J, He Q, Zhang X, Chang C, Pu Q: Efficacy and safety of CHG regimen (low-dose cytarabine, homoharringtonine with G-CSF priming) as induction chemotherapy for elderly patients with high-risk MDS or AMLtransformed from MDS. J Cancer Res Clin Oncol 2011, 137:1563-1569.

88. Brown D, Michaels S: Design and evaluation of oral delivery dosage forms of homoharringtonine [abstract]. Proc 98th Annual Meet Am Assoc Cancer Res 2007, 48:4730. abstract.

doi:10.1186/1756-8722-7-2

Cite this article as: Lü and Wang: Homoharringtonine and omacetaxine for myeloid hematological malignancies. Journal of Hematology \& Oncology 2014 7:2

\section{Submit your next manuscript to BioMed Central and take full advantage of:}

- Convenient online submission

- Thorough peer review

- No space constraints or color figure charges

- Immediate publication on acceptance

- Inclusion in PubMed, CAS, Scopus and Google Scholar

- Research which is freely available for redistribution 